\title{
Amphibians in the Wawer district of the Warsaw agglomeration
}

\author{
Joanna MAZGAJSKA \\ Society for the Protection of Amphibians and Reptiles "Tryton", Wiolinowa $7 \mathrm{~m}$ 8, 02-785 Warszawa; \\ e-mail:j.mazgajska@fotografie.waw.pl
}

\begin{abstract}
Studies on amphibians of permanent water bodies and marshes in the Wawer district of Warsaw were carried out in the spring of 2007. This terrain is situated on the right bank of the Vistula River, and is one of the least urbanized areas of the city. In this study, species composition, frequency of oceurrence and number of individuals on breeding sites were determined. Surprisingly, only six amphibian species were found, which was two times lower than found during previous research in the left bank area of Warsaw. The most common species occurring in Wawer were: moor frog (Rana arvalis) and common toad (Bufo bufo). Only $69.2 \%$ of permanent water bodies were inhabited by any amphibian species. To enable future comparative studies to be made on the impact of urban development and increased human activity on local amphibian populations, the precise locality of breeding sites were provided.
\end{abstract}

Key words: amphibians, urbanization, Warsaw, common toad, moor frog, common frog, declining of amphibians, habitat preferences

\section{INTRODUCTION}

The development of cities continues to progress and this inevitably leads to changes in animal populations in the urban environment (Marzluff et. al. 2008). Experts predict that with progressing urbanization, human populations living in urban areas will reach nearly 5 billion by 2030 (Hamer \& McDonnel 2008). Although relatively much information has been gathered on how urbanization influences birds or mammals (e.g. Kelcey \& Rheinwald 2005, Ree \& McCarthy 2005, Baker \& Harris 2007), amphibians - the most threatened group of vertebrates - are still rarely studied in this respect. The impact of humans and human-related environmental changes are considered the main factors responsible for the decline of amphibians throughout the world (Brito 2008), and urbanization is one of the most important activities altering their habitat (e.g. Bunnell \& Zampella 1999, Price at al. 2004, Bowles at al. 2006). It is estimated that one-third of amphibian species is currently threatened by urbanization (Hamer \& McDonnel 2008).

The main threats to amphibians in urban landscapes are the loss or degradation of habitats and their isolation (e.g. Lehtinen et al. 1999, Ficetola \& De Bernardi 2004, Burne \& Griffin 2005). The decline of amphibian species' diversity also results from the loss of aquatic/wetland vegetation (e.g. Bradford et al. 2003, Burne \& Griffin 2005, Drinnan 2005, Parris 2006), shading of water bodies by canopy cover (e.g. Bradford et al. 2003, Skelly et al. 2002) and fish restocking (especially with exotic species) (e.g. Brönmark \& Edenhamn 1994, Hecnar \& M'Closkey 1997, Kats \& Ferrer 2003). Amphibian egg development requires an appropriate water temperature, and the presence of natural shallows suitable for egg deposition at the proper depth is very important for many species (Strijbosch 1979). However, such elements of the aquatic environment are often eliminated in urban water bodies (Mazgajska 1996, Hamer \& McDonnel 2008)

Herpetologists emphasize the need to intensify amphibian urban ecology studies, especially monitoring long-term population trends, comparing species numbers, and determining population/individual conditions etc. before and after environmental changes or in the urban- 
suburban gradient (Hamer \& McDonnel 2008). Therefore, publications providing data on the condition of amphibian populations before environmental changes are made, supplemented by detailed descriptions of breeding ponds, are very important.

Until now, the amphibians of about fifteen Polish cities have been described in detail. Results of those studies revealed that the number of breeding amphibian species was significantly lower in ponds located in the central area than in suburban localities (Mazgajska 1996, Siwak et. al. 2000). As many amphibian species require an aquatic environment for breeding, the most important problem in Polish cities is the elimination of water bodies in many urban areas (Juszczyk 1989, Najbar et al. 2005, Mazgajska 2008). They are often filled in for road or building construction. Improper conservation and incompetent management of still existing ponds is a serious problem, at least in Polish cities (Życzyński \& Kiewicz 2006). Amphibian species distinctly differ in their tolerance of habitat changes related to urbanization. In Polish cities, the most common are usually those species considered habitat generalists, or those, which can find the specific conditions they favor. The green toad (Bufo viridis) and the common newt (Triturus vulgaris) are examples of the latter situation, both persisting in central parts of cities, successfully breeding in totally artificial ponds with concrete beds (e.g. Pawlowski 1993, Guzik et. al. 1996, Mazgajska 1996, Kierzkowski \& Ogielska 2001). Other species rarely found in cities, such as fire-bellied toad (Bombina bombina), northern crested newt (Triturus cristatus), common spadefoot (Pelobates fuscus) and common tree frog (Hyla arborea) were found almost exclusively in suburban areas in natural, shallow ponds with abundant reeds and other aquatic vegetation (Guzik at al. 1996, Mazgajska 1996, Mazgajska 2008).

One of the most comprehensive in Poland was the study of amphibians in 76 water bodies conducted in Warsaw, but mainly in the left bank area, which was generally subjected to longterm, strong urbanization pressures (Mazgajska 1996, Mazgajska 1998). However, some parts of Warsaw's outskirts continue to be less inhabited with low-density housing. Similar studies should be carried out in such places to enable comparisons to be made. The Wawer district, situated on the Vistula River's right bank, is an example of such an area, having been thus far less impacted by intensive urban changes. Previously, low, suburban, extensive family housing and open habitats prevailed in this area. However, intensive building investments, e.g. of housing estates with multi-story buildings, have started to be constructed within the last few years. Apart from the results of Derecka's (2005) study, which were too fragmentary, making their usefulness limited, there are no any amphibian studies for this part of Warsaw. Taking into consideration the distribution of amphibian species, almost all Polish lowland amphibians could occur there. Twelve of them were found in the left bank area of Warsaw (excluding Bufo calamita Laurenti, 1768) (Mazgajska 2008).

The aim of this study was to conduct a comprehensive inventory of amphibians and describe their breeding sites in the part of the Wawer district that is beginning to experience substantial environmental changes. This will enable future comparative studies to determine the influence of urban development and increased human activity on local amphibian populations.

\section{STUDY AREA}

Wawer is a district of Warsaw $\left(79.7 \mathrm{~km}^{2}\right)$ located in the southeast part of the city, along the right bank of the Vistula River, with ca. 63000 inhabitants. This district has one of the largest green belt areas of the city. Forests (34.8\%), agricultural lands and water bodies occupy in total $70 \%$ of Wawer surface. 


\section{WARSZAWA}

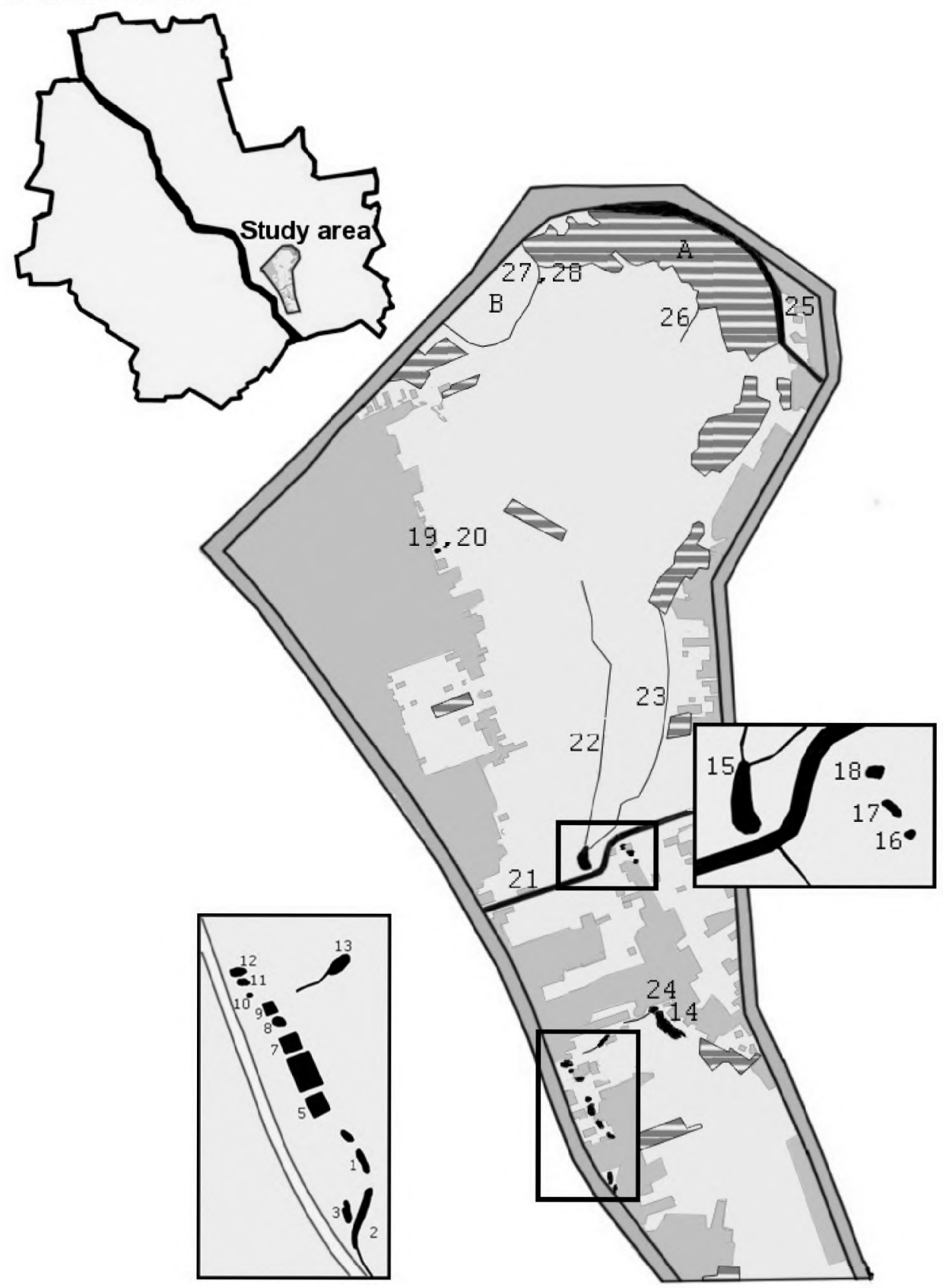

Fig.1. Situation of the research area in right bank of Vistula river in Warsaw, with detailed locations of studied water bodies; in gray - buildings, striped - forests; Landscape-Nature Protected Complex "Zakole Wawerskie": A - wetland forest, $\mathrm{B}$ - marsh overgrown with reeds. The water bodies are numbered as in Tables 1 and 2 . 
The study was carried out in the northwestern section of the district in an area of ca. $8 \mathrm{~km}^{2}$ : from Lacha Kuligowska in the south $\left(52^{\circ} 11^{\prime} \mathrm{N}, 21^{\circ} 07^{\prime} \mathrm{E}\right)$ to Nowa Ulga canal and Plowiecka Street in the north $\left(52^{\circ} 13^{\prime} \mathrm{N}, 21^{\circ} 08^{\prime} \mathrm{E}\right)$ (Fig. 1). Wal Miedzeszyński Street constitutes a western border of the study area, whereas Trakt Lubelski Street is its eastern border. Apart from the built-up areas, this district is made up of rather open landscape, with scarce afforestations and large areas covered by common reed (Phragmites australis). The northern part of the study area is covered by a wetland forest with black alder (Alnus glutinosa) (ca. 54 ha) and marsh marigold (Caltha palustris), marsh horsetail (Equisetum palustre), common comfrey (Symphytum officinale), yellow flag (Iris pseudoacorus) and valerian (Valeriana officinalis) in the herb layer. West of the forest is a small marsh overgrown with reeds Phragmites australis. As such marsh habitat is rare within the borders of the city, a LandscapeNature Protected Complex "Zakole Wawerskie" (ca. 54 ha) was created here. Both marsh areas - forests and reed beds - are important as breeding sites for amphibians.

Permanent water bodies occurring in the study area have been changed by humans to various degrees. The largest are the lakes in Łacha Zbytki and Jezioro Żabie. Several ponds create a complex in Lacha Kuligowska. This was previously probably one lake, but today the ponds are partially connected and form a system of floodways and flood-control reservoirs. At this moment, there are no water bodies radically changed by the urbanization processes (e.g. with concrete beds). Most ponds have banks strengthened by fascine, with shallow water and rush plants reduced to differing degrees. Jezioro Żabie has retained an extraordinarily natural character with large reed beds.

The study area has many ditches and canals. All of them are no wider than $1.5 \mathrm{~m}$. Many of the water bodies (mainly ponds) in the study area are located on private property.

\section{METHODS}

The study was carried out during one breeding season from the beginning of April to the end of June 2007. Observations were made by slowly moving along the shore line of a pond and recording all the amphibian adults, juveniles, spawn and larvae observed (see details in Mazgajska 1996). When it was necessary some individuals were caught for identification. The number of calling males was also noted. Each breeding site was examined 4-5 times. Because the identification of frogs from the Rana esculenta complex ( $R$. ridibunda Pallas, $1771, R$. lessonae Camerano, 1882, $R$. esculenta Linnaeus, 1758) is problematic, they were pooled to one "green frogs" group in the analysis.

Twenty-six permanent water bodies were examined (18 ponds and 8 canals or ditches). Two ponds from Lacha Kuligowska complex were not studied because they are located on private property with no public access. The open area of swamps overgrown with reeds and the marshy black alder forest of the Landscape-Nature Protected Complex "Zakole Wawerskie" were examined mainly by walking along transects and counting observed amphibian breeding sites.

In order to assess the number of individuals of particular amphibian species occurring in a specific water body, the highest number observed was considered. On that basis, four classes were distinguished: $1^{\text {st }}-$ from 1 to 20 individuals, $2^{\text {nd }}-$ from 21 to 100 individuals, $3^{\text {rd }}-101$ to 999 individuals, $4^{\text {th }}$ class - above 1,000 individuals.

The following physical features of water bodies were described: surface area (excluding marshes, pools and permanent flows), type of shoreline (e.g. natural rush, fascine, stakes) and periodicity (permanent or periodic). All manifestations of human activity were also noted such as: littering, polluting and partial or complete bulldozing of a pond. The surface area of water bodies was calculated from topographic maps (1:5000). In this study, local names of water bodies are used and their GPS coordinates are given to facilitate possible future comparative studies. 
To compare the average number of amphibian species in Wawer with results from the left bank area of Warsaw and from the Kozienice Forest outside of the city, data from Mazgajska (1998) and Dąbrowski \& Strużyński (2006) were recalculated and used. The Mann-Whitney test was used in the statistical analysis.

Table 1. Occurrence and relative abundance of amphibian species in the examined ponds; Shallow: presence $(+)$ or absence (-) of natural shallows, Reeds: A - lack of reeds on banks of pond, B - less than $1 / 4$ of ponds banks are covered by reeds, $\mathrm{C}$ - more or less than $1 / 2$ of pond banks are covered by reeds; + : - abundance from 1 to 20 individuals, ++from 21 to 100 individuals, +++ 101 to 999 individuals, ++++ - above 1,000 individuals; * - amphibians moved by pond owner in spring 2007 from Lacha Zbytki (pers. comm.); juv. - subadult, non-breeding individual, $\mathrm{X}$ - no data; Total - number of species breeding in each water body;

\begin{tabular}{|c|c|c|c|c|c|c|c|c|c|c|c|c|}
\hline \multirow[b]{2}{*}{ No } & \multirow[b]{2}{*}{ Pond } & \multirow[b]{2}{*}{ Location } & \multirow[b]{2}{*}{ 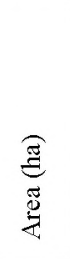 } & \multirow[b]{2}{*}{$\frac{\text { 容 }}{\overline{\bar{z}}}$} & \multirow[b]{2}{*}{ 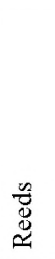 } & \multicolumn{6}{|c|}{ Species } & \multirow[b]{2}{*}{ Total } \\
\hline & & & & & & 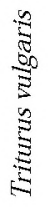 & $\begin{array}{l}\stackrel{\Xi}{\Xi} \\
\stackrel{\Xi}{\Xi} \\
0\end{array}$ & 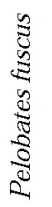 & 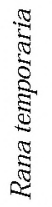 & 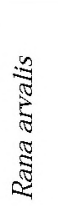 & 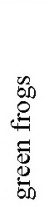 & \\
\hline 1 & Lacha Kuligowska 1 & $\begin{array}{l}\text { N } 52^{\circ} 11.546^{\prime} \\
\text { E } 21^{\circ} 07.553\end{array}$ & 0.10 & + & B & - & - & - & - & - & - & 0 \\
\hline 2 & Lacha Kuligowska 2 & $\begin{array}{l}\text { N } 52^{\circ} 11.434^{\prime} \\
\text { E } 21^{\circ} 07.542^{\prime}\end{array}$ & 0.20 & + & $\mathrm{C}$ & - & + & - & ++ & ++ & - & 3 \\
\hline 3 & Lacha Kuligowska 3 & $\begin{array}{l}\text { N } 52^{\circ} 11.437^{\prime} \\
\text { E } 21^{\circ} 07.515^{\prime}\end{array}$ & 0.08 & + & $\mathrm{C}$ & - & - & - & - & - & - & 0 \\
\hline 4 & Lacha Kuligowska 4 & $\begin{array}{l}\text { N } 52^{\circ} 11.546^{\prime} \\
\text { E } 21^{\circ} 07.553^{\prime}\end{array}$ & $\mathrm{X}$ & - & B & $\mathrm{X}$ & $\mathrm{X}$ & $\mathrm{X}$ & $\mathrm{X}$ & $\mathrm{X}$ & $\mathrm{X}$ & $X$ \\
\hline 5 & Lacha Kuligowska 5 & $\begin{array}{l}\text { N } 52^{\circ} 11.640^{\prime} \\
\text { E } 21^{\circ} 07.411^{\prime}\end{array}$ & 0.24 & - & A & - & + & - & - & - & - & 1 \\
\hline 6 & Lacha Kuligowska 6 & $\begin{array}{l}\text { N } 52^{\circ} 11.713^{\prime} \\
\text { E } 21^{\circ} 07.359^{\prime}\end{array}$ & $\mathrm{X}$ & - & A & $\mathrm{X}$ & $\mathrm{X}$ & $\mathrm{X}$ & $X$ & $\mathrm{X}$ & $\mathrm{X}$ & $\mathrm{X}$ \\
\hline 7 & Lacha Kuligowska 7 & $\begin{array}{l}\text { N } 52^{\circ} 11.702^{\prime} \\
\text { E } 21^{\circ} 07.370^{\prime}\end{array}$ & 0.14 & + & B & - & + & - & + & - & - & 2 \\
\hline 8 & Lacha Kuligowska 8 & $\begin{array}{l}\text { N } 52^{\circ} 11.640^{\prime} \\
\text { E } 21^{\circ} 07.411^{\prime}\end{array}$ & 0.10 & - & A & - & - & - & - & - & - & 0 \\
\hline 9 & Lacha Kuligowska 9 & $\begin{array}{l}\text { N } 52^{\circ} 11.444^{\prime} \\
\text { E } 21^{\circ} 07.334^{\prime}\end{array}$ & 0.08 & + & B & - & + & - & - & + & - & 2 \\
\hline 10 & $\begin{array}{l}\text { Lacha Kuligowska } \\
10\end{array}$ & $\begin{array}{l}\text { N } 52^{\circ} 11.757^{\prime} \\
\text { E } 21^{\circ} 07.309^{\prime}\end{array}$ & 0.03 & + & $\mathrm{C}$ & - & - & - & - & + & - & 1 \\
\hline 11 & $\begin{array}{l}\text { Lacha Kuligowska } \\
11\end{array}$ & $\begin{array}{l}\text { N } 52^{\circ} 11.770^{\prime} \\
\text { E } 21^{\circ} 07.277^{\prime}\end{array}$ & 0.06 & + & A & - & - & - & - & - & - & 0 \\
\hline 12 & $\begin{array}{l}\text { Lacha Kuligowska } \\
12\end{array}$ & $\begin{array}{l}\text { N } 52^{\circ} 11.795^{\prime} \\
\text { E } 21^{\circ} 07.235\end{array}$ & 0.14 & + & B & - & - & - & - & + & - & 1 \\
\hline 13 & Jezioro Sporne & $\begin{array}{l}\text { N } 52^{\circ} 11.772-796^{\circ} \\
\text { E } 21^{\circ} 07.460-465\end{array}$ & 0.09 & + & B & - & + & - & - & $\begin{array}{c}+ \\
\text { juv. }\end{array}$ & - & 1 \\
\hline 14 & Lacha Zbytki & $\begin{array}{l}\text { N } 52^{\circ} 11.882-824^{\prime} \\
\text { E } 21^{\circ} 07.720-824^{\prime}\end{array}$ & 0.85 & + & $\mathrm{C}$ & - & ++ & - & - & +++ & + & 3 \\
\hline 15 & Jezioro Żabie & $\begin{array}{l}\text { N } 52^{\circ} 12.295^{\prime} \\
\text { E } 21^{\circ} 07.400^{\prime}\end{array}$ & 0.33 & + & $\mathrm{C}$ & - & ++++ & - & ++ & ++ & - & 4 \\
\hline 16 & Wodniaków st, 1 & $\begin{array}{l}\text { N } 52^{\circ} 12.237^{\prime} \\
\text { E } 21^{\circ} 07.641\end{array}$ & 0.03 & - & A & - & - & ++ & - & ++ & - & 2 \\
\hline 17 & Wodniaków st. 2 & $\begin{array}{l}\text { N } 52^{\circ} 12.258^{\prime} \\
\text { E } 21^{\circ} 07.609^{\prime}\end{array}$ & 0.04 & - & B & - & ++ & - & + & + & $+*$ & 4 \\
\hline 18 & Wodniaków st. 3 & $\begin{array}{l}\text { N } 52^{\circ} 12.282^{\prime} \\
\text { E } 21^{\circ} 07.576^{\circ}\end{array}$ & 0.04 & - & B & - & + & - & - & + & - & 2 \\
\hline 19 & Poprawna st. 1 & $\begin{array}{l}\text { N } 52^{\circ} 13.139^{\prime} \\
\text { E } 21^{\circ} 06.861^{\prime}\end{array}$ & 0.04 & + & $\mathrm{C}$ & - & - & ++ & - & ++ & - & 2 \\
\hline 20 & Poprawna st. 2 & $\begin{array}{l}\text { N } 52^{\circ} 13.214^{\prime} \\
\text { E } 21^{\circ} 06.861^{\prime}\end{array}$ & 0.03 & + & $\mathrm{C}$ & - & - & - & - & - & - & 0 \\
\hline
\end{tabular}


Table 2. Occurrence of amphibian species in the permanent flows (canals and ditches); explanations as in Table 1.

\begin{tabular}{|c|c|c|c|c|c|c|c|c|c|}
\hline \multirow[b]{2}{*}{ No } & \multirow[b]{2}{*}{ Flow } & \multirow[b]{2}{*}{ Location } & \multicolumn{6}{|c|}{ Species } & \multirow[b]{2}{*}{ Total } \\
\hline & & & 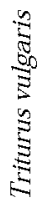 & $\begin{array}{l}0 \\
5 \\
0 \\
0 \\
0 \\
01\end{array}$ & 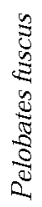 & 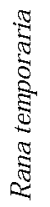 & 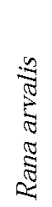 & 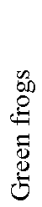 & \\
\hline 21 & Nowe Ujście canal & $\begin{array}{l}\text { N } 52^{\circ} 12.25^{\prime} \text { E } 21^{\circ} 08.01^{\prime} \\
-\mathrm{N} 52^{\circ} 12.07^{\prime} \text { E } 21^{\circ} 06.57^{\prime}\end{array}$ & - & - & - & - & $\begin{array}{l}+ \\
+ \\
\text { juv. }\end{array}$ & - & 0 \\
\hline 22 & Rów Zerzeński & $\begin{array}{l}\text { N } 52^{\circ} 12.17^{\prime} \text { E } 21^{\circ} 07.24^{\prime} \\
-N^{\circ} 12.53^{\circ} \text { E } 21^{\circ} 07.26^{\prime}\end{array}$ & - & - & - & - & - & - & 0 \\
\hline 23 & Rów Żabi & $\begin{array}{l}\text { N } 52^{\circ} 12.295^{\prime} \text { E } 21^{\circ} 07.400^{\prime} \\
-N^{\circ} 52^{\circ} 12.873^{\prime} \text { E } 21^{\circ} 07.129^{\prime}\end{array}$ & - & $\begin{array}{c}++ \\
+\end{array}$ & - & + & ++ & - & 3 \\
\hline 24 & Ditch near Lacha Zbytki & $\mathrm{N} 52^{\circ} 11.908^{\prime}$ E $21^{\circ} 07.688^{\prime}$ & - & + & - & - & + & - & 2 \\
\hline 25 & Nowa Ulga canal & $\begin{array}{l}\text { N } 52^{\circ} 13.56^{\prime} \text { E } 21^{\circ} 07.11^{\prime} \\
-N^{\circ} 13.32^{\circ} \text { E } 21^{\circ} 08.05^{\prime}\end{array}$ & - & - & - & - & - & - & 0 \\
\hline 26 & $\operatorname{ditch} 6$ & N $52^{\circ} 13.612^{\prime}$ E $21^{\circ} 07.764^{\prime}$ & + & ++ & - & + & + & - & 4 \\
\hline 27 & $\operatorname{ditch} 7$ & N $52^{\circ} 13.522^{\prime}$ E $21^{\circ} 08.077^{\prime}$ & - & - & - & + & - & - & 1 \\
\hline 28 & $\operatorname{ditch} 8$ & N 52 $13.605^{\prime}$ E $21^{\circ} 07.815^{\prime}$ & - & - & - & - & + & - & 1 \\
\hline
\end{tabular}

\section{RESULTS}

Six amphibian species were found in the study area: common newt (Triturus vulgaris (Linnaeus, 1758)), common toad (Bufo viridis Laurenti, 1768), common spadefoot (Pelobates fuscus (Laurenti, 1768)), common frog (Rana temporaria Linnaeus, 1758), moor frog (Rana arvalis Nilsson, 1842) and "green frogs" (Rana esculenta complex) (Table 1 \& 2). Breeding amphibians were found in $69.2 \%$ of permanent water bodies in the study area (ponds, lakes and permanent flows). The moor frog was the most frequently observed amphibian species in the studied ponds (Fig. 2). Only between 1 to 4 species were recorded in a pond. The average number $( \pm \mathrm{SD}$ ) of amphibian species breeding in one permanent water body was $1.46 \pm 1.3$. The mean number of breeding amphibian species in one water body is significantly lower in the study area $(Z=2.09, \mathrm{p}<0.05)$ than in the left bank area of Warsaw (mean -2.14 , Mazgajska 1998). Also, the average number of breeding amphibian species per pond both in the left bank area of Warsaw as well as in the right bank Wawer district was significantly lower than the same results for the Kozienice Forest area, also located in the Mazovian Lowland (respectively $Z=4.16, p=0.0001, Z=4.29, p<0.0001$ ).

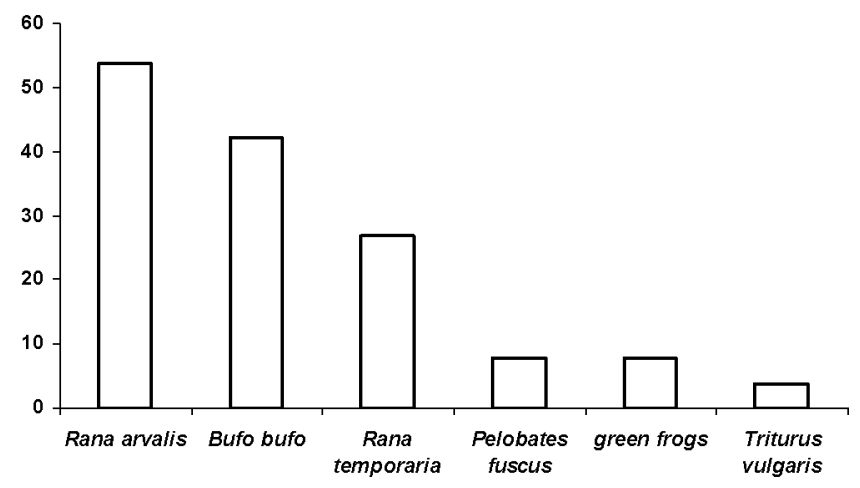

Fig .1 Frequency (\%) of amphibian species occurring in the study permanent water bodies. 
During investigations of the open marshy terrain of the Landscape-Nature Protected Complex "Zakole Wawerskie" covered by common reed, five breeding sites of Rana arvalis and one of $R$. temporaria were found. In the black alder forest marsh area, three breeding sites of $R$. temporaria and one of $R$. arvalis were found. In the open area west of this terrain, wandering common toads were observed (in about 10 localities, 1-10 individuals in each site). The number of observed breeding individuals in a breeding site ranged from a few to about one thousand. One common toad breeding site (Jezioro Żabie and the ditch running from it, "Rów Żabi") was extraordinarily numerous and contained about one thousand individuals. However, mass breeding (above 100 individuals) was observed in only a few ponds (Table 3 ).

Table 3. Number of breeding individuals of each species in breeding sites.

\begin{tabular}{|l|c|c|c|c|c|c|}
\hline \multirow{2}{*}{$\begin{array}{c}\text { Number of } \\
\text { individuals }\end{array}$} & \multicolumn{7}{|c|}{$\begin{array}{c}\text { Number of ponds (\%) with amphibian species } \\
\text { vulgaris }\end{array}$} & Bufo bufo & $\begin{array}{c}\text { Pelobates } \\
\text { fuscus }\end{array}$ & $\begin{array}{c}\text { Rana } \\
\text { temporaria }\end{array}$ & Rana arvalis & $\begin{array}{c}\text { Rana esculenta } \\
\text { complex. }\end{array}$ \\
\hline $1-20$ & $1(100 \%)$ & $7(58.3 \%)$ & - & $4(66.6 \%)$ & $9(60.0 \%)$ & $2(100 \%)$ \\
\hline $21-100$ & - & $3(25.0 \%)$ & $2(100 \%)$ & $2(33.3 \%)$ & $5(33.3 \%)$ & - \\
\hline $101-999$ & - & $1(8.3 \%)$ & - & - & $1(6.6 \%)$ & - \\
\hline$>1000$ & - & $1(8.3 \%)$ & - & - & - & - \\
\hline
\end{tabular}

During the study, bank destruction and the partial bulldozing of four ponds were observed (Lacha Kuligowska 2, Lacha Kuligowska 7, Lacha Zbytki, Poprawna 1). It is also known from owners that they plan to fill in two other water bodies (Lacha Kuligowska 8, Wodniaków 3). Four of the examined ponds are used by residents as a rubbish dump. Three seem to be polluted by waste from the production of pickled vegetables (Lacha Kuligowska 1, Lacha Kuligowska 2, Eacha Kuligowska 3). At least five water bodies are used as fishing ponds and are successively restocked (Lacha Kuligowska 5, Lacha Kuligowska 6, Lacha Kuligowska 8, Wodniaków 2, Wodniaków 3). The Lacha Kuligowska 10 pond was almost completely dry during the entire time of the study.

\section{DISCUSSION}

Of the 12 species occurring in the left bank area of Warsaw (Mazgajska 2008), only 6 were found in the study area. Considering the relatively natural character of water bodies and lowdensity housing of Wawer, this is surprisingly low. Aside from Warsaw, more amphibian species have also been found in other Polish cities than in the Wawer area, e.g.: 12 in Bialystok and Lublin (Siwak et al. 2000, Chobotow \& Czarniawski 2007), 11 in Poznan, Kraków, Zielona Góra and Olawa (Pawłowski 1993, Guzik et al. 1996, Najbar et al. 2005, Majtyka 2006), 10 in Chorzow and Gniezno (Soltysiak 2004, Adamiak 2008), 9 in Wroclaw (Kierzkowski \& Ogielska 2001) and 8 in Walbrzych (Bałuka 2000). Also, the average number of amphibian species recorded per one breeding pond was significantly lower than in the much more urbanized, left bank area of Warsaw. Despite the low frequency of amphibian species in the study area, some of them, such as the common toad or moor frog, breed in a few water bodies in great numbers, such as Bufo bufo in Jezioro Żabie.

Generally, specific amphibian species chose water bodies for breeding in agreement with their ecological preferences cited in the literature (Juszczyk 1987), e.g. "brown frogs" bred in both permanent and temporary water bodies, whereas "green frogs" and common toad occurred exclusively in permanent ponds (Dąbrowski \& Strużyński 2006). According to previous research (e.g. Juszczyk 1987), none of the species bred in canals, where the current is too fast for Polish lowland amphibian species. The only fragmentary population of "green 
frogs" (Rana esculenta complex), inhabiting $7.7 \%$ of permanent water bodies in the study area, is surprising. They occurred in $56.6 \%$ of breeding ponds on the left bank of Warsaw (Mazgajska 1998), and "green frogs" were also the most common amphibians in the suburban habitat of Italy (Ficetola \& De Bernardi 2004). In the study area, "green frogs" were found in only two ponds, and in one these, they were artificially introduced in the spring of 2007 (pond owner's personal comment).

Despite the much smaller number of water bodies examined than in the left bank of Warsaw, two breeding sites of Pelobates fuscus were found in the study area, thus it occurs in $7 \%$ of ponds studied, similar to results of the study carried out in the left bank area of the city (6\%, Mazgajska 1996). Those two ponds are important at the scale of the city, as common spadefoot is one of the four rarest amphibian species of Warsaw, besides the common tree frog, fire-bellied toad and northern crested newt (Mazgajska 1996).

The frequency of Rana temporaria in the study area is $26.9 \%$. This is greater than in the left bank area of Warsaw (18.4\%). This species is very sensitive to the lack of moisture (Frafjord \& Byrkjedal 1994) and is withdrawing from Warsaw, but it is still relatively common in the Wawer area. Its main refuge is the Landscape-Nature Protected Complex Zakole Wawerskie, where this species mainly breeds.

The study revealed that moor frog has the most numerous breeding sites in the study area (at least 19 ponds and pools). Its frequency approaches 53.8\%, whereas in Mazgajska's (1996) study on the left bank of city, it reached $27.6 \%$.

Although some amphibian species inhabiting the study area demonstrate a higher frequency in the water bodies of Wawer than in the left bank area of Warsaw, it is puzzling that only $69.2 \%$ percent of water bodies are occupied by any amphibian species. In the left bank area of the city, this figure was as high as 95\% (Mazgajska 1996). In the more rural terrain of Kozienice Forest, amphibians occupy $91.2 \%$ of its ponds.

At this moment, there is no unequivocal explanation of such low species diversity and low frequency of amphibians in Wawer's breeding ponds. One of the reasons may be pond pollution and people's treatment of some water bodies as a rubbish dump. On the other hand, some water bodies are used as fishing ponds. They are successively stocked, deprived of shallow water and have their reeds reduced. These activities enhance fish predation of amphibian eggs, larvae and metamorphosed individuals, causing the reduction of amphibian numbers (Fog 1988, Hamer \& McDonnel 2008).

When we also consider the increasing pressure of urbanization in this area, it is possible that the status of amphibian species will deteriorate. The majority of water bodies are situated on private property, which makes any conservation effort to improve amphibian habitat difficult. On the other hand, the cleaning and adaptation of areas around new housing estates could lead to water body restoration, and thus create better breeding sites for amphibians. Also, the construction of new artificial water bodies in areas belonging to the City of Warsaw next to destroyed ponds could be a solution to prevent the advancement of amphibian decline. Of great importance is to enhance the level of protection for the Landscape-Nature Protected Complex "Zakole Wawerskie", the refugium of Warsaw's declining population of "brown frogs". This is also an important area for many rare bird species. For years, a nature reserve has been planned for this area, but it has never been established. A second herpetologically very valuable terrain, unique in the city, requiring protection is Jezioro Żabie with its surrounding open reed beds.

Amphibian population changes in this area should continue to be monitored in future studies. 


\section{ACKNOWLEDGEMENTS}

I am grateful to: Dr Tomasz Mazgajski for his valuable comments to the manuscript and assistance with the field work, Ms Ewa Mazgajska for her help in the field work, Mr Dominik Mikiewicz for determining water body surface areas and Dr Michal Fic for advice on hydrological terminology and information about the hydrological system in the Wawer area.

\section{REFERENCES}

ADAMIAK W. 2008. Local species of amphibians and the number of their seats in the Gniezno area. In: ZAMACHOWSKI W. (ed.), Biologia Plazów i Gadów - Ochrona Herpetofauny. LX Ogólnopolska Konferencja Herpetologiczna, 22 23.09.2008, Kraków, pp. 15-18, Wydawnictwo Naukowe Akademii Pedagogicznej, Kraków, 188 pp. [In Polish]

BAKER P. J. \& HARRIS S. 2007. Urban mammals: what does the future hold? An analysis of the factors affecting patterns of use of residential gardens in Great Britain. Mammal Review. 37: 297-315.

BA£UKA B. 2000. Studies on the herpetofauna of Wałbrzych. In: ZAMACHOWSKI W. (ed.), Biologia płazów i gadów. V Ogólnopolska Konferencja Herpetologiczna, 26-28.06.2000, Kraków, pp. 10-12. Wydawnictwo Naukowe Akademii Pedagogicznej, Kraków. [In Polish]

BRADFord D. F., NEALE A. C., NASH M. S., SADA D. W. \& JAEgER J. R. 2003. Habitat patch occupancy by toads (Bufo punctatus) in a naturally fragmented desert landscape. Ecology 84: 1012-1023.

BRITO D. 2008. Amphibian conservation: Are we on the right track? Biological Conservation 141: 2912-2917.

Bowles B. D., SANDERS M. S.\& HANSEN R. S. 2006. Ecology of the Jollyville Plateau salamander (Eurycea tonkawae: Plethodontidae) with an assessment of the potential effects of urbanization. Hydrobiologia 553: 111- 120.

BRÖNMARK C \& EDENHAMN P. 1994. Does the presence of fish affect the distribution of tree frogs (Hyla arborea)? Conservation Biology 8: 841-845.

BUNNELL J. F. \& ZAMPELLA R. A. 1999. Acid water anuran pond communities along a regional forest to agro-urban ecotone. Copeia 1999: 614-627.

BURNE M.R. \& GRIFFIN C. R. 2005. Habitat associations of pool-breeding amphibians in eastern Massachusetts, USA. Wetlands Ecology and management. 13: 247-259.

CHOBOTOW J. \& CZARNIAWSKI W. 2007. Płazy i Gady Lublina. Chrońmy Przyrodę Ojczysta. 63: 21-37.

ClAUSNITZER H. J. 1983. Zum geminsamen Vorkommen von Amphibien und Fischen. Salamandra 19: 158-162.

DĄBROWSKI J. \& STRUŻYŃSKI W. 2006. The diversity of amphibian species in water bodies of Kozienice Forest. Fragmenta Faunistica 49: 153-163.

DERECKA A. 2005. Płazy Warszawy [Amphibians of Warsaw]. Master Thesis, Szkoła Główna Gospodarstwa Wiejskiego, Wydział Nauk o Zwierzętach, Katedra Biologii Środowiska Zwierząt, Warszawa. [In Polish]

DRINNAAN I.N. 2005. The search for fragmentation thresholds in a southern Sydney suburb. Biological Conservation 124: 334-349.

GUZIK M., SCHIMSCHEINER L., ZAKRZEWSKI M., ZAMACHOWSKI W. \& ZYŚK A. 1996. Herpetofauna miasta Krakowa. Studia Ośrodka Dokumentacji Fizjograficznej. 22: 247-262.

HAMMER A. J. \& MCDONNEL M. J. 2008. Amphibian ecology and conservation in the urbanizing world: A review. Biological Conservation 141: 2432-2449.

HECNAR S. J. \&. M'CLOSKEY R. T.1997. The effects of predatory fish on amphibian species richness and distribution. Biological Conservation 79: 123-131.

FICETOLA G.F. \& DE BERNARDI F. 2004. Amphibians in a human-dominated landscape: the community structure is related to habitat features and isolation. Biological Conservation 119: 219-230.

FRAFJORD K. \& BYRKJEDAL I. 1994. Terrestrial habitat use by frogs and toads, Rana temporaria L. and Bufo bufo (L) in west Norway. Fauna Norvegica, Ser. A. 15: 25-28.

FoG K. 1988. An investigation of all ponds with Hyla arborea on the island of Als, Dk. 2. Statistical treatment of results. Memoranda Societatis pro Fauna et Flora Fennica 64: 122-123.

JUSZCZYK W. 1987. Plazy i gady krajowe. Vol. 2 \& 3. PWN, Warszawa, 384 pp. +213 pp.

JUSZCZYK W. 1989. Plazy i gady Krakowa w latach 1922-1979. Przegląd Zoologiczny 33: 373-381.

KATS L.B. \& FERRER R. P. 2003. Alien predators and amphibian declines: review of two decades of science and the transition to conservation. Diversity and Distributions 9: 99-110.

KELCEY J. G. \& RHEINWALD G. 2005. Birds in European Cities. Ginster Verlag, Katharinen, Germany, 450 pp.

KIERZKOwski P. \& OGIELsKa M. 2001. Amphibians of Wrocław. Chrońmy Przyrodę Ojczysta 57: 65-80 [In Polish]

LEHTINEN R. M., GaLatowitsch S. M. \& TESTER J. R. 1999. Consequences of habitat loss and fragmentation for wetland amphibian assemblages. Wetlands 19: 1-12.

MAJTYKa T. 2006. Preferencje siedliskowe plazów w Olawie. In: SZYMCZYK R., MARCZAK D., PEPEOWSKAMARCZAK D. \& LIŚNIANísKi P.(ed.), Materialy X Ogólnopolskiego Przeglądu Działalności Kół Naukowych Przyrodników, 20-21.10.2006, Olsztyn, pp. 49-52. Uniwersytet Warmińsko- Mazurski, Olsztyn, 100 pp. 
Marzluff J. M., Shulennerger E., Endlicher W., Alberti M., Bradley G., Ryan C., ZumBrunnen C.\& Simon U. 2008 (eds), Urban Ecology. Springer-Verlag, Berlin, 808 pp.

MAZGAJSKA J. 1996. Distribution of amphibians in urban water bodies. (Warsaw agglomeration, Poland). Ekologia Polska 44: 245-257.

MAZGAJSKA J. 1998. The studies on batrachofauna in Warsaw in 1992-1994. In: BARCZAK T. \& INDYKIEWICZ P. (eds), Urban fauna, pp. 231-240. Akademia Techniczno Rolnicza, Bydgoszcz, 263 pp. [In Polish]

MAZGAJSKA J. 2008. Changes in the amphibian community of Warsaw water bodies in the last fifteen years. In: ZAMACHOWSKI W. (ed.), Biologia Płazów i Gadów - Ochrona Herpetofauny. IX Ogólnopolska Konferencja Herpetologiczna, 22-23.09.2008, Kraków, pp. 66- 67, Wydawnictwo Naukowe Akademii Pedagogicznej, Kraków, 188 pp. [In Polish]

NaJBar B., Szuszkiewicz E. \& PIETRUszka T. 2005. Plazy Zielonej Góry i zanikanie ich siedlisk w granicach administracyjnych miasta w latach 1974-2004. Przegląd Przyrodniczy 49: 155-166.

PARRIS K. M. 2006. Urban amphibian assemblages as metacommunities. Journal of Animal Ecology 75: 757 - 764.

Pawlowski A. 1993. Plazy miasta Poznania [Amphibians of Poznań Agglomeration]. Master Thesis, Uniwersytet Adama Mickiewicza, Zakład Zoologii Ogólnej, Poznań, 82 pp. [In Polish]

PRice S. J., DOCORAS M. E., GaLlant A. L, KLAVER R. W. \& WLLSON J. D. 2006. Three decades of urbanization: estimating the impact of land-cover change on stream salamander populations. Biological Conservation 133: 436-441.

Price S. J., MARKS D. R., Howe R. W., HANOWSKi J. M. \& NEMI G. J. 2004. The importance of spatial scale for conservation and assessment of anuran populations coastal wetlands of the western Great Lakes, USA. Landscape Ecology 20: 441-454.

REE R. \& MCCARTHY M. A. 2005. Inferring persistence of indigenous mammals in response to urbanization. Animal Conservation. 8: 309-319.

RICHTER K. O. \& AZOUS A. L. 1995. Amphibian occurrence and wetland characteristics in the Puget Sound Basin. Wetlands 15: 305-312.

Siwak P., Kossakowski R. \& CHĘTNICKI W. 2000. Amphibians of Bialystok. In: LATOWsKi K. (ed.), Studia biologiczne, pp. 117- 121. Bogucki, Poznan, 173 pp. [In Polish]

SKELLY D. K., FREIDENBURG L. K. \& KIESECKER J. M. 2002. Forest canopy and the performance of larval amphibians. Ecology 83: 983-992.

SOLTYSIAK M. 2004. Inwentaryzacja miejsc występowania płazów w Chorzowie - wstępne wyniki badań. [The studies on batrachofauna in Chorzów - preliminary data]. In: ZAMACHOWSKI W. (ed.), Biologia Płazów i Gadów - Ochrona Herpetofauny, VII Ogólnopolska Konferencja Herpetologiczna, 28-29.09.2004, Kraków, pp. 122-116. Wydawnictwo Naukowe Akademii Pedagogicznej, Kraków, 194 pp. [In Polish]

STRJiBosCH H. 1979. Habitat selection of amphibians during their aqatic phase. Oikos 33: 363-372.

ŻYCZYISSKI A. \& KIEWICZ M. 2006. Ocena realizacji planu ochrony herpetofauny w Parku im. J. Pilsudskiego (Pola Mokotowskie). Przegląd Przyrodniczy 17: 63-71.

\section{STRESZCZENIE}

\section{[Plazy warszaw skiej dzielnicy Wawer]}

Wiosną 2007 roku przeprowadzono inwentaryzację batrachofauny, zarówno stałych jak i okresowych zbiorników wodnych na terenie Wawra. Ta dzielnica położona na prawym brzegu Wisły, jest jednym z najmniej zurbanizowanych obszarów Warszawy. Podczas badań ustalono sklad gatunkowy, frekwencję występowania oraz liczebność plazów w poszczególnych zbiornikach rozrodczych. Na terenie Wawra stwierdzono występowanie jedynie sześciu gatunków plazów - dwukrotnie mniej niż na lewobrzeżnych obszarach miasta. Najpospolitszymi gatunkami okazaly się żaba moczarowa (Rana arvalis) i ropucha szara (Bufo bufo). Jakiekolwiek gatunki plazów stwierdzono jedynie w 62,2\% stalych zbiorników wodnych. Zarejestrowanie stanowisk godowych w systemie GPS umożliwia dalszą kontrolę stanu batrachofauny tego obszaru w trakcie zmian urbanizacyjnych. 